\begin{tabular}{|l|l|l||}
\hline \multicolumn{2}{|c|}{ PublisherInfo } \\
\hline \hline PublisherName & $:$ & BioMed Central \\
\hline \hline PublisherLocation & $:$ & London \\
\hline \hline PublisherImprintName & $:$ & BioMed Central \\
\hline \hline
\end{tabular}

\title{
Methylcytosine and mutation
}

\begin{tabular}{|l|l|l||}
\hline \multicolumn{2}{|c|}{ ArticleInfo } \\
\hline \hline ArticleID & $:$ & 4536 \\
\hline \hline ArticleDOI & $:$ & $10.1186 /$ gb-spotlight-20020722-01 \\
\hline \hline ArticleCitationID & $:$ & spotlight-20020722-01 \\
\hline \hline ArticleSequenceNumber & $:$ & 202 \\
\hline \hline ArticleCategory & $:$ & Research news \\
\hline ArticleFirstPage & $:$ & 1 \\
\hline \hline ArticleLastPage & $:$ & 2 \\
\hline \hline & & RegistrationDate : 2002-7-22 \\
\hline ArticleHistory & $:$ & OnlineDate \\
\hline \hline ArticleCopyright & $:$ & BioMed Central Ltd2002-7-22 \\
\hline \hline ArticleGrants & $:$ & \\
\hline \hline ArticleContext & $:$ & 130593311 \\
\hline \hline
\end{tabular}




\section{Jonathan B Weitzman}

Email: jonathanweitzman@hotmail.com

MBD4 is a methyl-CpG-binding protein with thymine-DNA-glycolase activity that can remove T bases from T-G mismatches within a CpG context. In the July 19 Science, Millar et al. describe analysis of mice lacking the Mbd4 gene (Science 2002, 297:403-405). They generated Mbd4-/- knockout mice and bred them with the 'Big Blue' reporter strain to measure mutation frequency. They found that the knockout mice had a three-fold higher frequency of $\mathrm{C}$ to $\mathrm{T}$ transitions at $\mathrm{CpG}$ sites. Then Millar et al. tested the effect of $M b d 4$ mutation on cancer susceptibility. They crossed Mbd4-/- knockout mice with animals carrying the Min allele of the adenomatous polyposis coli gene (ApcMin). They observed increased tumor formation in the colon and $\mathrm{C}$ to $\mathrm{T}$ mutations in the $A p c$ gene. These results provide further evidence for the role of MBD4 in tumor suppression.

\section{References}

1. Role of MED1 (MBD4) Gene in DNA repair and human cancer

2. Science, [http://www.sciencemag.org]

3. Multiple intestinal neoplasia caused by a mutation in the murine homolog of the APC gene. 